\title{
Public Multicultural Music and the Australian State
}

\section{GRAEME SMITH}

In Australia, for the past decade or so, it has been commonplace for a shared social identity to be musically demonstrated in public ceremonies and celebrations by reference to cultural diversity. From massive national events like the opening and closing ceremonies of the Sydney Olympics, down to local municipal festivals, displays of difference-rather than musical genres which portray widely shared histories-are assigned the task of representing Australia. Thus what can be referred to as "public multicultural music" assumes the role of presenting the central character of the nation. ${ }^{1}$ This is the musical manifestation of a trope of public life and discourse that has evolved since the 1980s, whereby "multiculturalism" has become established as one of the most consistently cited characteristics of the Australian nation. Even the conservative Howard government, which attempted to circumscribe the centrality of multiculturalism in policy throughout its time in office (1996-2007), ${ }^{2}$ maintained its commitment to such descriptions of the nation as the following:

"Multicultural" is a term that describes the cultural and linguistic diversity of Australian society. Cultural and linguistic diversity was a feature of life for the first Australians, well before European settlement. It remains a feature of modern Australian life, and it continues to give us distinct social, cultural and business advantages.

The Australian Government's multicultural policy addresses the consequences of this diversity in the interests of the individual and society as a whole. It recognises, accepts, respects and celebrates our cultural diversity. ${ }^{3}$

Like all symbolic structures, the effectiveness of multicultural music to present this view of the nation depends on a sense that it emerges in a natural and organic way from reality, that it is "a reflection of our multicultural society." No such emergence is spontaneous, and this article will discuss the ways in which it has been created out of a combination of musical, organizational, and governmental activity.

The way in which "public multicultural music" came into a national role is intertwined with the development of multicultural arts policy, of particular genres of music and their audiences, and of organizations that would promote and foster these musical styles. Musicians, arts administrators in semigovernment organizations, entrepreneurs, and enthusiasts have all contributed. Policy developments over the past twenty years reflect changing notions of the role of the state in determining the relationship between the state and the individual citizen. The process began with the political moves to accommodate the social changes resulting from Australia's post-war migration.

At the end of World War II, Australia was a small nation of about seven million people with a declining birth-rate. The government embarked upon an ambitious immigration program, which

\footnotetext{
${ }^{1}$ Graeme Smith and Judith Brett, "Nation, Authenticity and Difference in Pop Music," Fournal of Australian Studies 58 (1998): $15-16$.

${ }^{2}$ Tim Soutphommasane, "Can the M-Word Survive?" New Matilda 8 November 2006, available at http://newmatilda.com/2006/11/08/can-m-word-survive\%3F (Accessed 27 April 2009).

${ }^{3}$ Department of Immigration and Citizenship "Fact Sheet no. 6: The Evolution of Australia's Multicultural Policy," revised 15 June 2007. Available at http://www.immi.gov.au/media/fact-sheets/06evolution.htm (Accessed 27 April 2009).
} 
transformed the demographic structure of Australian society. When preferred immigrants from the traditional source countries of Britain and Ireland proved to be insufficient to meet its target, the government looked to other sources, first to the displaced persons camps of Europe, then to northern and later southern Europe. ${ }^{4}$

As the numbers of immigrants increased, their presence and their social differences from AngloAustralians became significant. Immigrants from Italy, Greece, the Balkans, and the Middle East in particular were highly visible. ${ }^{5}$ For these people, cultural distance was reinforced by social and economic difference, many having emigrated from relatively economically depressed rural areas to enter at the bottom end of the Australian labour market. Immigrants brought with them local and national social customs and cultures that they could recognize as the source of their own identity, which they had no wish to discard, and which were often tenaciously maintained in a strange and potentially hostile new environment. Musical tastes, preferences and practices embedded in social life were important among them and a range of nationally distinctive popular entertainment genres were performed by musicians within communities. ${ }^{6}$

The musics immigrants played, listened, and danced to in their communities are part of the story of the development of multicultural music as a national Australian emblem. Emblematic folkloric styles were fostered by national and regional immigrant organisations to maintain immigrants' cultural heritages among their children. Much of this music, however, was limited in its appeal to broader audiences, and often these genres and their players tended to be circumscribed within specific communities and ethnic groups. The expansion of multicultural music into a more public sphere was more complex. Social institutions, musical movements, and actors from beyond ethnic communities have at least been as important in the process of claiming a public space as musicians embedded within immigrant social groups.

In the 1960s and 1970s migrant music was largely performed to meet the social and musical needs of the migrants themselves. Beginning in the second half of the 1970s and accelerating in the 1980s, however, ethnic musical forms started to gain a new public as groups of left-liberal activists embraced the politics of ethnicity and cultural pluralism that were given their first institutional expression in the tumultuous three years of the Whitlam Labor government (1972-75). Although an interest in and awareness of diverse musical genres and forms had been part of aesthetically adventurous popular music consumption in Australia at least since the early 1960s, growing support for the music of ethnic Australia was closely linked to the expansion of welfare and education services to migrants that occurred in the early 1970s. A general interest in the lives and backgrounds of migrants arose amongst those involved with policy, and political mobilization in this area coincided with an awareness of entrenched social disadvantage amongst migrants and their children. Migrant English teachers became the largest group of Anglo-Australians to engage with migrant groups, and these were later joined by social and health-care workers. These people went on to play an important part in the promotion of ethnic music in the 1980s, both as cultural activists and as audiences. Roger Holdsworth, Melbourne world music broadcaster and activist, has described how his musical taste developed from English language folk music to diverse genres, whether Bulgarian vocal

\footnotetext{
${ }^{4}$ There are many accounts of the origins and consequences of the Australia's post-war migration program. For an overview and a collection of relevant sources, see John Lack and Jacqueline Templeton, eds., Bold Experiment: Documentary History of Australian Immigration since 1945 (Melbourne: Oxford University Press, 1995), 2-16.

${ }^{5}$ Jock Collins, Migrant Hands in a Distant Land (Sydney: Pluto Press, 1988), 12.

${ }^{6}$ For some examples of the range of these distinctive ethnic musics see Peter Parkhill, notes to the compact disc set Transplanted Musical Traditions in Australia (Melbourne: Sound Heritage Australia, 2003), AHS06.
} 
music or flamenco or the rebetika music that drifted over the back fence from his Greek neighbours. In the 1970s Holdsworth was a leading activist in the so-called "inner suburban group" of radical teachers, proposing innovative school democratizations and attempting to forge links with migrant parent constituencies. Holdsworth's trajectory is a good example of the confluence of the values of the New Left with the expansion of new class strata delivering post-war state services to migrants. His educational activism fostering political and community action moved easily into his work as an influential public radio presenter and promoter of migrant and world music genres in Melbourne. ${ }^{7}$

This musical and cultural interest in migrant Australia was part of an alliance between the Labor Party (and the left in general) and non-English speaking migrants, and was cemented by the Whitlam government. Gough Whitlam was the first party leader in Australian political history to directly address ethnic Australia, in his "It's Time" campaign for the 1972 election; he was particularly successful in winning southern European immigrant votes to Labor. The Australian left began to forge links with allied groups within the ethnic communities, such as the Italian Communist Party-influenced social welfare organization FILEF, and the Greek organization of democratic youth. ${ }^{8}$

Once elected, the Whitlam government expanded the provision of government services to nonEnglish speaking migrants, with a significantly changed understanding of the bargain between the new immigrants and the host society. No longer was the onus primarily on the newcomers to prove their worth through assimilation, but on the government to remove the discriminatory barriers that were making full participation in Australian society difficult for many non-English speaking migrants. ${ }^{9}$ In 1974 , Al Grassby, Whitlam's Minister for Immigration, signaled the beginning of a radical reorientation of representations of Australian national identity to accommodate the reality of an ethnically mixed population and the rights of non-British migrants to social and cultural expression. In what was the first official statement defining Australia in terms of its diversity as "a multi-cultural society for the future," Grassby said, "It would seem a mark of national maturity to be able to identify firstly what is essential and distinctive about one's own land and its people, and then to portray it consistently with insight and sympathy. It is a fact that Australia is now one of the most cosmopolitan societies on earth." Recognized and fostered, diversity was not a source of social problems but, on the contrary, would ensure national strength. $^{10}$

The Whitlam government was also elected with an ambitious policy of promoting Australian artistic and cultural life. Creative artists were seen to be important for national prestige, and the culture they produced as essential for a civilized society. Hence, creative artists and cultural institutions were deserving of thoughtful and generous government support. ${ }^{11}$ The Australian Council for the Arts, the government's official arts funding body established by the Liberal government a few years earlier, was upgraded in 1973, and its funding was doubled. In 1975 it was given statutory authority status and its name changed to the Australia Council. Along with the seven art-form based boards, such as the Music, Dance and Literature Boards, the restructured Council included a Community Arts Fund, which provided support to

\footnotetext{
${ }^{7}$ Roger Holdsworth, "Radio Journal,” 3rd (Winter 1997): 15; interview with the author, 24 August 2005.

${ }^{8}$ Simone Battiston, "History and Collective Memory of the Italian Migrant Workers' Organization FILEF in 1970s Melbourne" (doctoral thesis, Latrobe University, School of European and Historical Studies, 2004), 87-104.

${ }^{9}$ See Ann-Mari Jordens, Alien to Citizen: Settling Migrants in Australia, 1945-75 (Sydney: Allen \& Unwin, 1997), Chapter 9.

${ }^{10}$ Al J. Grassby, “A Multi-cultural Society for the Future,” Canberra: Australian Government Publishing Service, 1973. Available at http://www.multiculturalaustralia.edu.au/doc/grassby_1.pdf (Accessed 27 April 2009).

${ }^{11}$ Gay Hawkins, From Nimbin to Mardi Gras: Constructing Community Arts (St. Leonards: Allen and Unwin, 1993), 30-32; Anne Pender, "The Mythical Australian: Barry Humphries, Gough Whitlam and 'New Nationalism," Australian fournal of Politics and History 51, no. 1 (2005): 67-68.
} 
community-based arts activities, and a Community Development Committee, which quickly established itself as a forum for debating questions of elitism and access to the arts. Recognizing the distance between the Council, the official arts, and migrants, the CDC moved to establish an Ethnic Arts Committee in 1975. Although the conservative Fraser government that came to power in 1975 attempted to reshape the Australia Council, the institutions committed to cultural democracy and ethnic representativeness could not be easily rooted out. The Ethnic Arts Committee was quickly disbanded, but the Community Arts and Development Committee proved itself to be a formidable force, and emerged from this crisis upgraded to a Board in 1978, with similar institutional power to the other boards. From its newly consolidated institutional position as the Community Arts Board, it continued and advanced its support of arts projects emanating from ethnic communities. ${ }^{12}$

Initially the Australia Council had limited impact on ethnic cultural activity. A handful of groups gained some support, but the traditional art boards were dismissive of the idea of specific migrant needs. A survey commissioned by the Community Arts and Development Committee in 1977 and executed by Gail Holst, a scholar of Greek music, found that ninety percent of the ethnic groups surveyed did not know of the existence or purpose of the Council. ${ }^{13}$ In 1978, the government's Review of Post Arrival Programs and Services for Migrants, chaired by lawyer Frank Galbally, argued for the even-handed delivery of public services to non-English speaking residents, and for their right to cultural support similar to that available to Anglo-Australians. The Review was highly critical of the Australia Council, and recommended that it should both build up links with ethnic communities and "reassess its budgetary allocation in order to ensure that ethnic arts receive a more equitable amount." 14 Galbally's review implicitly argued that the responsibilities of the Australia Council were primarily to the Australian people, rather than to the imagined integrity of selected art forms, a view reinforced in 1982 by another review of Council policy in relation to ethnic arts, this time by the Australian Institute of Multicultural Affairs. In response, the Australia Council established several incentive funds, one of which was for Multicultural Arts, and the Boards dedicated to specific art forms were asked to put forward programs meeting certain criteria. As a result, funding for ethnic artists and programs increased threefold between 1982 and $1985 .{ }^{15}$ The Music Board, although initially wary of these impositions, was distributing grants amounting to $\$ 131,000$ to ethnic and multicultural music by 1984. Outside the established institutions of opera companies and orchestras, "Ethnic and Multicultural Music" was used by the Music Board as a category of funding distribution in this period, alongside genre categories such as Jazz, Folk, and Music Theatre. ${ }^{16}$

Money was allocated in a number of ways: direct grants for recording assistance, grants to individual artists for professional development, or contributions to the salaries of ethnic arts and community arts officers jointly supported by the Community Arts Board, and by state and local governments. The community arts movement, that most politically inflected area of cultural policy, acted on various fronts: through youth policy, support for local and regional community activity, innovative arts practice and so on, and for music seen as "naturally" emergent from ethnic communities. Ultimately, the most influential

\footnotetext{
${ }^{12}$ Gay Hawkins, "Reading Community Arts Policy: From Nimbin to the Gay Mardi Gras," Media Information Australia (August, 1989): 31-33; Annette Blonski, "Persistent Encounters: The Australia Council and Multiculturalism," in Culture, Difference and the Arts, ed. Sneja Gunew and Fazal Rizvi (Sydney: Allen \& Unwin, 1994), 192-206; Carmen Grostel and Gillian Harrison, Community Arts and Its Relation to Multicultural Arts, in Gunew and Rizvi, 147-64, esp. 149-50.

${ }^{13}$ Blonski, 198.

${ }^{14}$ Ibid., 199.

${ }^{15}$ Ibid., 198-203.

${ }^{16}$ Australia Council, "Analysis of State and Federal Funding Category by Musical Style 1984-5; Australia Council, Music Board Medium Range Plan 1985-1989, Sydney: Australia Council, 1986, Appendix 1, 3.
} 
recipients of this support were a number of organizations which became centers for the promotion and performance of ethnic music. These were the Boite in Melbourne (founded in 1979), the Peña in Sydney (1980), the Ethnic Music Centre of Western Australia (1983), and the Brisbane Ethnic Music and Arts Centre (1987). ${ }^{17}$ These centers became more influential than the ephemeral grants awarded to particular performances or individuals. ${ }^{18}$

Thus, the funding policies of the Australia Council during the 1980s established the base from which music could be used as a primary public expression of multiculturalism, both through continuing funding of institutions for the staging of appropriate musical representations, and through direct support of some individual musicians, for recording, touring, and the like.

Public multicultural music was not called into existence by bureaucratic fiat, however important financial support may have been to sustain it. Public policy provided the framework, but the music that resulted was created by the enthusiasts and innovative artists who were cultivating an interest in this area. As the rhetoric of multiculturalism took shape as a model for national identity, however, it provided musicians and audiences with a readymade explanation of their social significance and a means of explaining their affective links with the music. If the music was to be, as many promotional documents described it, an "expression of our multicultural society," then the act of playing and listening signaled a participation in this social good, and brought it into vibrant existence.

A number of ethnic fusion bands formed in the 1980s, producing music which, in its wide ranging conjunction of sounds and styles, placed itself as an authentic and organic manifestation of the emergent public multiculturalism. These groups had established their position within the popular music soundscape in Australia well before the international marketing promotion of world music in the late $1980 \mathrm{~s} .{ }^{19}$ When, in the 1990s, the genre of world music consolidated its connotations, its marketing style, and its approach to its audience, such Australian musicians were able to situate themselves within its ambit.

These were essentially folk-rock style bands, using unfamiliar instruments from non-western folk and traditional genres, and offering eclectic interpretations of diverse musical styles. They were primarily made up of Anglo-Australian musicians from folk and progressive rock backgrounds, who combined a taste for exotic sounds with a social and musical idealism and romanticism, and who imagined a national popular music based on a blend of ethnic and foreign styles.

One influential group of performers emerged from the countercultural student Aquarius festival held in the northern New South Wales country town of Nimbin in 1973. Individuals from this group, in the next decade or two, formed such bands as Sirocco, Gondwanaland, Mara! and others. At the Aquarius festival, they were connected to a progressive rock and performance group calling itself the White Company, which included such performers such as Linsey Pollack, Peter Carolan and Guy Madigan, each of whom played important roles in polyethnic fusion bands in the 1980s. ${ }^{20}$ Linsey Pollak, for example, introduced many Anglo-Australian musicians to Balkan music. He had heard Macedonian music on

\footnotetext{
${ }^{17}$ For a detailed study of one of these organizations see Graeme Smith, "Playing with Policy: Music, Multiculturalism and the Boite," in Music, Migration and Multiculturalism, ed. Kay Dreyfus and Joel Crotty, Victorian Historical Fournal 78, no. 2 (2007): 152-69.

${ }^{18}$ See Michelle Duffy, "Music of Place: The Performance of Identity in Contemporary Australian Community Music Festivals" (doctoral thesis, University of Melbourne, 2001), 58-66; Regional and Community Music Coordinators' reports, Australia Council, August 1986 (in author's possession).

${ }^{19}$ For an account of the coining of the term "world music," see Timothy Taylor, Global Pop: World Music, World Markets (London: Routledge, 1997), 1-5.

${ }^{20}$ For a retrospective view of some of the activities of this performance group, see http://compendium.carolan.info/WhiteCo/WhiteCompany.htm (Accessed 15 April 2009).
} 
record in the 1970s and was immediately struck by the sound of the gajda, a Macedonian bagpipe with a non-tempered scale and a powerful tone that played a stream of richly ornamented and rhythmically complex asymmetrical dance melodies.

Pollak pursued his interest amongst musicians and instrument makers in London in 1977-78, later spending some time in Macedonia. When he returned to Australia, he linked up with Macedonian immigrants, as well as with other Anglo-Australian musical enthusiasts with adventurous musical ears who identified their own taste and musical ability with the diversity that was being advanced in Australian multicultural policy. Around this time, having already established his own small musical scene in Sydney, Pollak made contact with the Australia Council. In 1983 he was funded by the Council as foundation ethnic music officer of the North Perth Ethnic Music Centre. This organization fostered many performances by ethnic musicians and was regarded as highly effective by the Council.

Sirocco was one of the most successful of the bands that formed at this time. Bill O'Toole, one of the founding and continuing members, traces the core of the membership and the group's musical inspiration to musicians linked to the White Company group and to the Renaissance Players, an innovative early music group centered at Sydney University. ${ }^{21}$ O'Toole states that in developing his original conception of Sirocco, he looked for musicians with rock sensibilities_rhythmic drive, and a taste for performance theatricality. He specifically avoided folk musicians who "were fairly laid back performers, what I needed was a dance band to play the sort of music that I'd seen throughout Europe and that I knew was here in Australia, which was multicultural music. I needed to get musicians who had a lot of stick." 22 Musicians entered this multicultural fusion band field via a number of pathways. O'Toole relates that he was inspired by the music he heard in travels in Europe in the late 1970s, as were other influential musicians of this style. O'Toole was a founding member of the seminal English folk-rock band Blowzabella, whose powerful combination of percussion and ethnic modal dance melody would provide the basis of Sirocco's sound. ${ }^{23}$

\section{Audio EXAMPLE 1: "Rant Part II"}

Accessible at: http://dx.doi.org/10.3998/mp.9460447.0003.202

"Rant Part II" (Andrew de Teliga) from The Breath of Time (ABC recordings 842 738-1) (1990) by the group Sirocco (Guy Madigan, percussion; Andrew de Teliga, guitar; Bill O’Toole, bombarde; Charlie McMahon, didjeridu). Music (c) Larrikin Music Publishing Pty Ltd. International Copyright Secured. All Rights Reserved. Used with permission of Larrikin Music Publishing Pty Ltd. Recording used courtesy of the Australian Broadcasting Corporation.

\footnotetext{
${ }^{21}$ See the website of this group at http://www.myspace.com/therenaissanceplayers (Accessed 29 June 2009).

${ }^{22}$ Quote from Bill O’Toole, interview with Mark Dunbar, cited in Mark Dunbar, “'All Take, Take, Take....' Migrant Musicians, the Australia Council, Multiculturalism and Music Making in Australia” (master's thesis, Monash University, 1990), 12.

${ }^{23}$ See http://www.blowzabella.com (Accessed 30 September 2008). Linsey Pollack was also associated with this band. See Bill O'Toole, "New Traditions," in Australia: Exploring the Musical Landscape, ed. Caitlin Rowley (Sydney: Australian Music Centre, 1998), 24.
} 


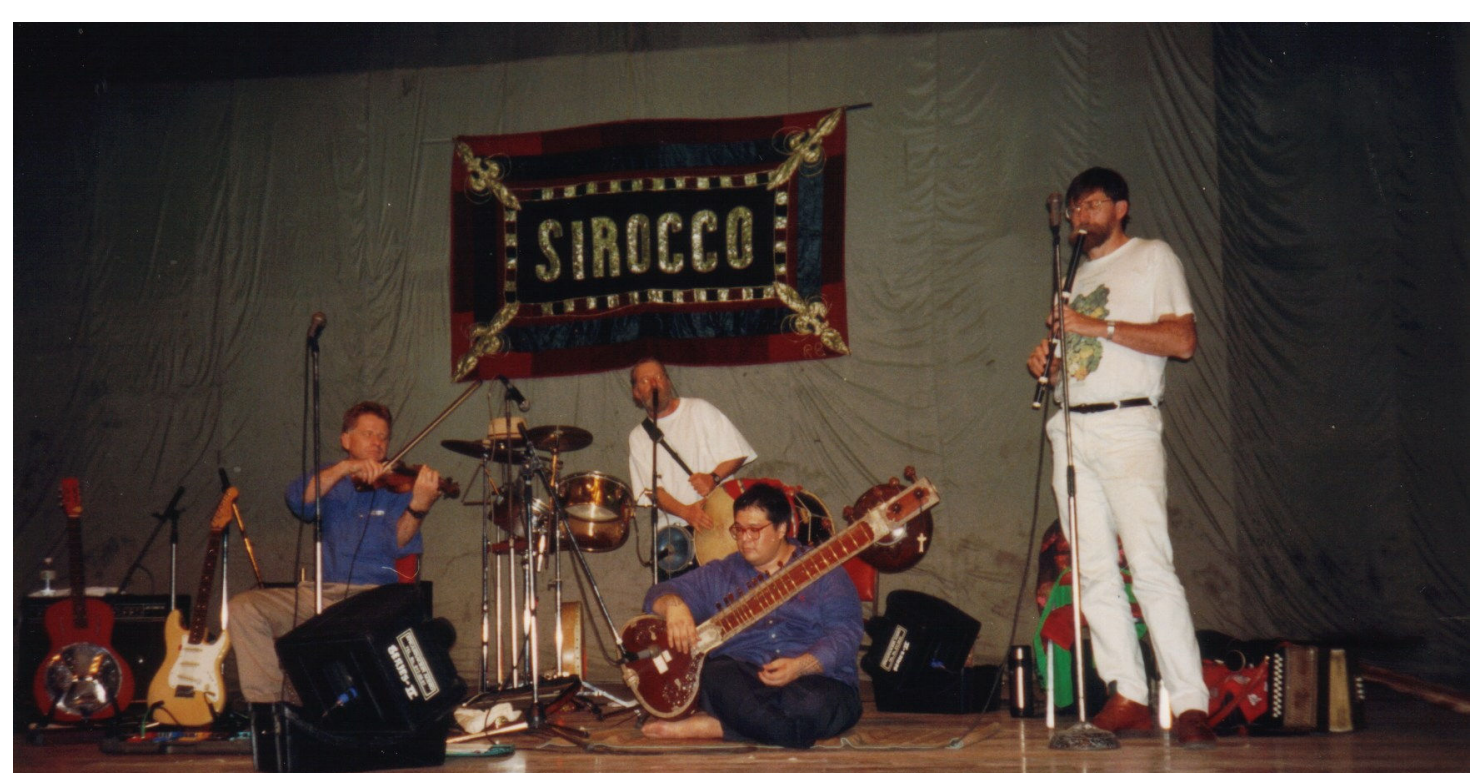

Figure 1. Sirocco rehearsing in Manila 1990 with Pilipino sitar player, Joey Valenciano. Left to right: Andrew de Teliga, Guy Madigan, Joey Valenciano, Bill O’Toole. (Photograph courtesy Bill O'Toole; used with permission.)

Sirocco, still active, has altered its line up and modes of playing over the two decades of its existence, but has generally consisted of a core of three musicians playing a variety of exotic instruments, especially of the bagpipe and oboe-like shawm families, combined with a range of percussion instruments and standard electric guitars. The music varies from ambient and programmatic numbers to strongly rhythmic dance pieces.

Australian musicians playing in genres such as these were connected with the politics of multiculturalism in two ways. They were the recipients of some government funding, sometimes directly through grants of assistance or more often indirectly through performance bookings at supported festivals. Moreover, they also tended to justify and promote themselves within the rhetoric of multiculturalism. By 1990 Sirocco promoted itself thus:

In ten years the band has toured Korea, India, China, U.S.A., New Zealand and even Norfolk Island, not to mention most states of Australia bringing its unique style of music to the folk. It's not rock-but contains the excitement of rock and roll, it's not folk but draws for its inspiration on the multicultural folk music of Australia and it's not classical and yet the band has a chamber approach to their music"New Tradition" is the only apt term for this style of music. ${ }^{24}$

Sirocco and other similar groups performed in pubs, public concerts, and festivals. Supported by the selfprojection and performance skill of the performers, as well as the theatrical effect of exotic costumes, the new musical resources which these musicians marshalled attracted large audiences. Their styles and contexts of presentation did not aim at audiences within specific ethnic communities but were accessible to Australians of all backgrounds. They were widely read as an expression of the new understanding of Australian society which multiculturalism was attempting to create. In this period, as noted, the Music Board of the Australia Council was eager to find "multicultural musicians," and these Anglo-based fusion

${ }^{24}$ Cover notes from Sirocco, The Breath of Time, LP ABC 842 738-1 (1990). 
groups had a particular attraction to funding bodies because they fitted easily into narratives of national cultural development. ${ }^{25}$ Almost uniquely among the officially supported art forms, musicians had a model of the way in which such expressive forms could be incorporated into a central high art tradition. The schools of nationalist composition of nineteenth-century Europe that based great international art on national folk styles were well-known to the western art musicians who dominated the Music Board. Even if such a national music aesthetic stance was often seen as outdated in the late twentieth century, it was at least understood. Thus, though fusion bands were employing a different means of compositionproducing a recording rather than creating a written score-they could be seen as national composers, mediating and presenting folk forms to display a national soul. So, for example, fifteen grants for recording assistance were made between 1985 and 1989 within the multicultural arts quota set by the Council. Three of these were granted to migrant performers or groups, seven to various predominantly Anglo-Australian interpretative groups producing polyethnic fusions, and the remainder to a choice of organizations for compilation recordings, themselves fostering the idea of a musical melting pot. ${ }^{26}$

Mark Dunbar, adopting a highly critical stance, has argued that much of this musical activity was essentially created by Australia Council funding, and that most initial support for multicultural music was directed towards arts administrators or musicians of English-speaking origin, rather than to migrant musicians. Yet to read this situation as an example of cultural exclusion is overly simplistic. Musical fusion groups, such as Sirocco, were inclusive of musicians from a variety of folk and other cultural traditions and were congruent to the ideals of a national culture implicit in the Australia Council's brief. ${ }^{27}$

If the ethnic fusion groups that formed in this period elicited some disquiet in their social representations, a number of cultural revival groups with closer links to ethnic communities were more directly able to undertake the symbolic role of publicly enacting multicultural Australia. ${ }^{28}$ Greek retrorebetika revival groups were active and popular, as were those following the styles of the Italian folk movement of the 1970s, or the Latin American Andean and New Song movements. They were often made up of young second-generation migrants. Others comprised first-generation migrant performers, often middle-class professionals and musical hobbyists committed to cultural rejuvenation and maintenance. ${ }^{29}$ Such groups were popular choices at folk festivals, drawing a socially concerned non-ethnic audience. Unlike old-fashioned national folkloric ensembles, or professional entertainment bands catering to ethnic communities, these musicians addressed audiences in familiar modes that combined didactic with entertainment functions. Their music tended to be constructed on the patterns of musical revivalism outlined by ethnomusicologist Tamara Livingston and others. For Livingston, music revivals tend to be social movements led primarily by middle-class enthusiasts who,

position themselves in opposition to aspects of the contemporary cultural mainstream, align themselves with a particular historical lineage, and offer a cultural alternative in which legitimacy is grounded in reference to authenticity and historical fidelity. ${ }^{30}$

\footnotetext{
${ }^{25}$ Annette Blonski, Arts for a Multicultural Australia 1973-1991 (Sydney: Australia Council, 1992), 20.

${ }^{26}$ Dunbar, 6, 71-72.

${ }^{27}$ Ibid., 71-4, 87-95.

${ }^{28}$ For an example of this critique, see Peter Parkhill, "Multicultural Music: The dark side of the myth," in M.A.T.I.A. Music II, eds. A. Kefala and A. Karakostas-Seda (Sydney: Australia Council, 1987), 47-48.

${ }^{29}$ Greg Borschmann, “The New Folk Music,” Age, 21 March 1986, EG 10-11; Stathis Gaunlett, “The Diaspora Sings Back:

Rebetika Down Under," in Greek Diaspora and Migration since 1700, ed. D. Tziovas (Farnham: Ashgate, 2009 ), $279-83$.

${ }^{30}$ Tamara Livingston, “Music Revivals: Towards a General Theory,” Ethnomusicology 43, no. 1 (1999): 66.
} 
Revivals tend to interpret musics within familiar frameworks of "modern" and "traditional," and thus provide a basic framework for listening, despite any unfamiliarity or exoticism of sound:

Certain aesthetic preferences are also predominant: precision in playing and of tone production, tight arrangements, privileging of contrast over continuity, all of which are geared towards performance for an audience. $^{31}$

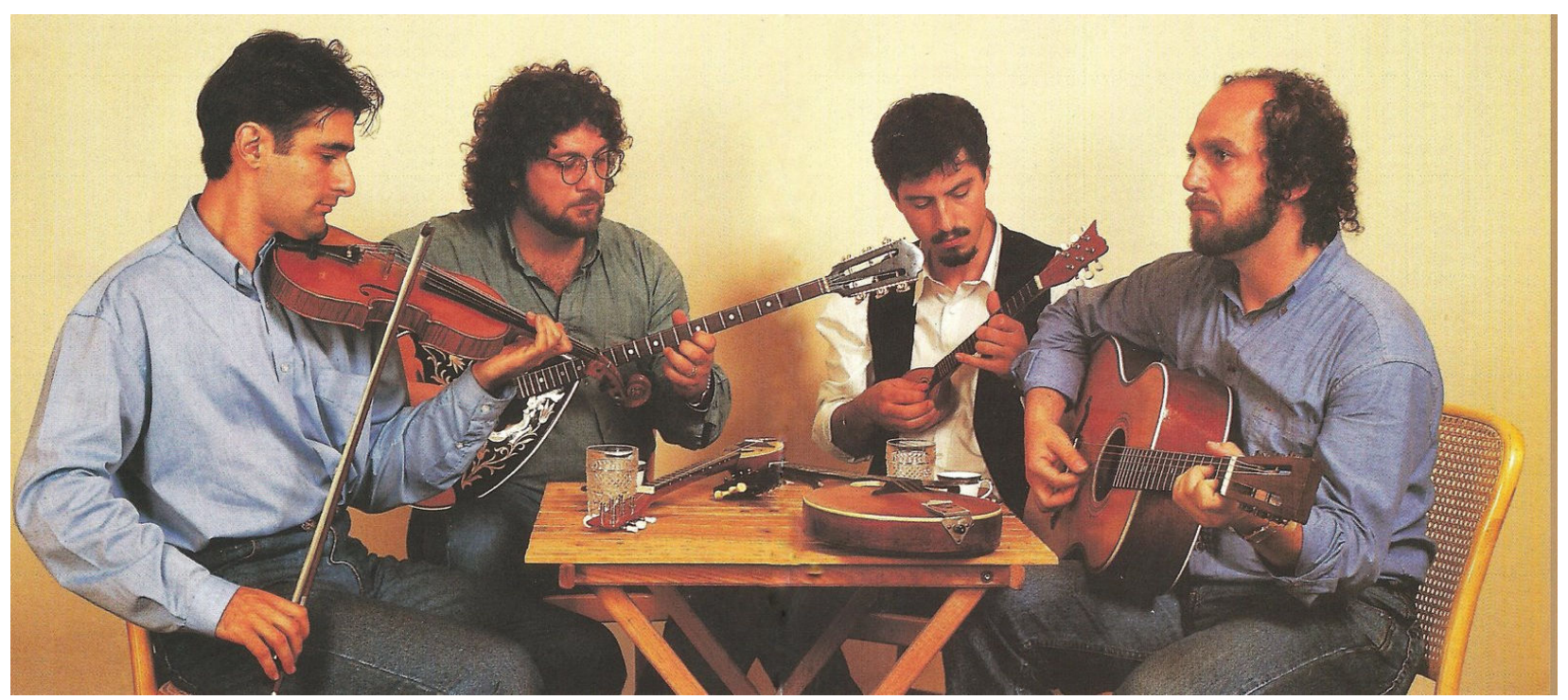

Figure 2. Apodimi Compania (1992): (left to right) Hector Cosmas, Manuel Galiatsos, Archie Argyropoulos, George Galiatsos. (Photograph Geoff Hollings. Used with permission of Brunswick Recordings.) Apodimi Compania was a successful and highly skilled group of young Greek-Australian rebetika players in Melbourne, active from 1984 to the mid-1990s.

\section{Audio Example 2: "In Marigo's Hash-den"}

Accessible at: http://dx.doi.org/10.3998/mp.9460447.0003.202

"In Marigo's Hash-den" (Spiros Peristeris) from CD album Melisma (1992) by the group Apodimi Compania (Brunswick Recordings BRCD17). Recording used courtesy of Brunswick Recordings. (http://www.acrosstheborders.com.au/cdshop-titles.htm)

When player aficionados described rebetika as "Greek Blues," audiences were immediately provided with ways to place the music socially and historically, which could suggest to them how it might be fitted into an imagined cultural mosaic. Although these cultural revival groups did not usually attempt to create musical content which could represent multiculturalism as a totality, through such strategies as deliberately including musical or textual elements indexing Australian cultural interaction, they could present an image of ethnic cultures operating within a pluralist patchwork of cultural equivalence. ${ }^{32}$

Musical groups, performers and styles that were presented and promoted as multicultural music in a public arena outlined relationships between the nation, its constituent groups, and individual citizens.

\footnotetext{
${ }^{31}$ Livingston, 77.

${ }^{32}$ Graeme Smith, Singing Australian: A History of Folk and Country Music (Melbourne: Pluto Press, 2005), $155-59$.
} 
Policies facilitated and supported certain forms and styles, but also provided public frameworks and discourses through which audiences and performers understood the music. Through the 1980s, the idea of Australian multiculturalism as a defining feature of the national society was consolidated. By 1988 Australia Council arts policy directed toward "Multicultural Arts" was repositioned as "Arts for a Multicultural Australia." This marked a gradual move away from the goal of providing support for socially excluded communities as a policy motivation. The focus was shifting towards a more abstract conception of the nation, the ideal nature of which should be "multicultural," and of the arts as a part of the journey towards this goal. Nonetheless, policies through the early 1990s still aimed to "support and develop activities of persons and communities of a non-English speaking background." By 1998, however, policy was relabelled as Australia Council Policy on Australian Arts and Cultural Diversity, and the nation, rather than particular groups within it, became the subject. ${ }^{33}$ This change was partly a response to attempts by the conservative Howard government, elected in 1996, to diminish the place of multiculturalism in public discourse. The Howard government came to office with the hegemonic national policy slogan "for all of us," intent on dismantling multiculturalism, which it saw as linked to the concerns of "special interest groups." Though the initial antipathy was to some degree weakened by the realities of administration, its spirit continued through the Howard government's four terms (1996-2007).

In 2006, after a period of review initiated by the Australia Council's Multicultural Advisory Committee, the focus again shifted with the policy document Arts in a Multicultural Australia. ${ }^{34}$ The change of the preposition (from "for" to "in") encapsulated the relocations of the previous decade. Any idea that multicultural policy should be directed toward fostering a hitherto incompletely realized social ideal is removed. In explanation, the document states that "our Australian community as a whole is multicultural" and, importantly, subsumes indigenous Australians into that multiculturalism, where previous policies had recognized that their relationship to the nation could not be thus subsumed.

The phrase "multicultural arts" is sometimes perceived as relevant only in a community and ethnic context. Australian multicultural arts practice is in fact represented by a variety of expressions ranging from ethno-specific and bi-cultural, intra-cultural to cross-cultural and nation to nation inter-cultural exchange. Similarly, "multicultural art" is not synonymous with community art. The Arts in a Multicultural Australia policy endorses the view that our multicultural arts practice is relevant across the entire spectrum of arts activity. ${ }^{35}$

Multicultural arts is thus not defined in terms of social groups and communities, and "issues of access, equity and maintenance of cultural heritage" are to some degree replaced by "a desire to also highlight artists and their practice." 36

The shifts in multicultural arts policy during the period of the Howard government progressively removed any suggestion that such policies were a response to structural social or cultural inequalities. Further, the power of institutions such as ethnic community groups to mediate between the individual and the nation was to be limited. ${ }^{37}$ However, these changes of emphasis were not merely the consequence of the policy direction of a particular conservative national government, but also a manifestation of global

\footnotetext{
${ }^{33}$ Australia Council, Policy on Arts for a Multicultural Australia (Sydney: Australia Council, 1993); Arts in a Multicultural Australia, 2006.

${ }^{34}$ Arts in a Multicultural Australia.

${ }^{35}$ Ibid., 13.

${ }^{36}$ Ibid., 10.

${ }^{37}$ See Soutphommasane.
} 
changes in the ways in which ethnic and cultural social difference in society was being understood and managed in many constituencies.

In his transnational overview of policy aimed at cultural and social diversity in Europe and Canada, cultural policy theorist Tony Bennett discerns three developmental stages. The first is typified by support for ethnic minority cultures, and focus on issues of preservation and an "embattled relationship with the mainstream." The second aims to resolve the excessively dichotomous relationships of the first stage and to diffuse criticisms of ethnic separatism. Here the nation becomes a pluralist federation of ethnicities, under overarching limitations of civic responsibility. In this period the "mainstream" itself is ethnicized. The third and current stage is characterized by the identification and affirmation of cultural diversity and of its constitutive role in the formation of the nation. Here "it is the intersections and intermixings of, and crossovers between, different cultural perspectives and traditions that produce the social dynamics for forms of cultural diversity that constantly interpenetrate one another with new and unpredictable consequences." ${ }^{38}$ But this diversity within the nation is not just the result of the global mobility of discrete population groups. The fields of cultural and postcolonial studies and the conceptions embedded within them have penetrated policy. ${ }^{39}$ Thus third stage multiculturalism policy has incorporated ideas of fluidity and hybridity that see cultures not as discrete categories but rather as constituting a field over which individuals move, constantly redefining complex and contradictory identities. ${ }^{40}$

This trajectory has, broadly speaking, been followed by Australia, and is reflected in music policy and the musical activities and approaches which have been favored and supported. The first stage can be aligned with the ethnic rights movement that was the foundation of the first awareness of multicultural music, and of the sense of social justice which underpinned the cultural aspects of the Galbally report. The second stage of cultural pluralism produced public multicultural music which could address a broad audience, yet still plausibly be seen as emerging from ethnic communities. As Australian policy has moved into the third stage, we see alterations in the justifications for support and in the types of musical acts that fit into the presentation of the multicultural state. Public multicultural music has tended to be promoted not as representing the positions of specific ethnic groups within Australian society, but as constituting the ideal way in which identity is creatively constructed.

This move from "community" to "identity" has been supported by the ascent of the category of world music as the most easily understood and "natural" representation of multicultural music. When the genre emerged in the 1980s and 1990s, it significantly revised ideas of informed consumption, which had imbued musical forms from the non-western developing world as maintaining authenticity through their expression of cultural continuities and depth. Where previous presentations of multicultural music tended to be within the discursive frameworks of tradition, cultural maintenance and cultural rights, world music identified and fostered new styles of popular stylistic fusions and individual innovations. The music was now ideally an expression of the agency of hitherto marginalized musicians, whose authenticity and value did not necessarily emerge from an imagined relationship to a social or cultural community. In world

\footnotetext{
${ }^{38}$ Tony Bennett, Differing Diversities: Transversal Study on the Theme of Cultural Policy and Cultural Diversity (Strasbourg: Council of Europe Publishing, 2001), 58-59.

${ }^{39}$ See Pierre Bourdieu and Loïc Wacquant, "Neoliberal Newspeak: Notes on the New Planetary Vulgate," Radical Philosophy 105 (2001): 2-5.

${ }^{40}$ For example, Stuart Hall, "Old and New Identities, Old and New Ethnicities," in Culture, Globalisation and the World System: Contemporary Conditions for the Representation of Identity, ed. A. King (London: Macmillan, 1991), 41-68; J. Rutherford, "The Third Space: Interview with Homi Bhabha," in Identity, Community, Culture, Difference (London: Lawrence and Wishart, 1990), 207-21.
} 
music discourse, the distance between musicians and a social group presumed to be a focus of representation can be elevated to a positive. Hybridity and fusion become the marks of a new form of authenticity, and music is seen as a "site on which new sorts of (hybrid) identity are being performed." 11 Thus, the genre of world music enables new alignments of the ways in which music can be understood as multicultural.

Crucial to this view is the way in which artists project their identity. In this public display of identity some artists may emphasize their personal heritage, which becomes part of a performance persona and a source of authority; for others, their musical styles and genres become performance masks adopted with a playful or ironic acceptance of their contingency. Aline Scott-Maxwell has described such explorations of individual identity among several prominent Australian world music artists of the last few years. ${ }^{42}$ To perform in the space of public multicultural music in the current period, musicians need not claim an organic relationship with an ethnic community. Although heritage and ancestry can be part of the way in which such musicians claim the authenticity of their musical utterance, these are likely to be rediscovered or reemphasized cultural roots, rather than a simple expression of upbringing. The career of singer songwriter Kavisha Mazella exemplifies such a process of rediscovery. Born Paola Mazella, with an Italian father and a "Burmese and Irish/Scots mother," she settled into her position as a song-writer eloquently indexing an immigrant background after more general experience in Australian folk-clubs and alternative countercultural movements. Around 1988 she was engaged in a community arts project researching the songs of Italian women in Fremantle, Western Australia, a project which led to her being commissioned by Deckchair Theatre in Perth to provide music for the play Emma Celebrazione, based around an Italian woman's migration story. She consequently formed a couple of highly acclaimed Italian "community choirs," which have sung at many festivals and public events. ${ }^{43}$ She claims a respectful relationship to the non-professional singers she has welded into a group that can be staged as a historical representation of a generation of migrants. Through the 1990s, Mazella released a number of highly acclaimed albums, with many songs describing the experience of migrant women, displaced from home. Her song-writing thus became a journey to rediscover her ancestors, and she has acknowledged in interview the importance of "go[ing] on your own ancestral journey ... to discover who you are." ${ }^{44}$ As both a performer and musical impresaria she exemplifies a type of elective ethnicity, exercising the "ethnic options" described by Mary Waters in her study of second-generation ethnic Americans. ${ }^{45}$

Narratives of self-discovery are common. Often international travel rather than local inter-cultural interaction forms the background to the music that is projected as representing multicultural Australia. Travelers form themselves as adventurers and hopeful insiders to cultural difference, and in this contemporary tale of self-realization, they take home knowledge, experience, and an internalized status. For many musicians of this group, world music is the sound track to a Bildungsroman. For example, musician Anne Harkin is an active performer of Middle Eastern and African drumming. Herself of Anglo-

\footnotetext{
${ }^{41}$ Simon Frith, "The Discourse of World Music," in Western Music and Its Others: Difference, Representation and Appropriation in Music, ed. Georgina Born and David Hesmondhalg (Berkeley: University of California Press, 2000), 310.

${ }^{42}$ Aline Scott-Maxwell, "Localising Global Sounds: World Music and Multicultural Influences in Australia," in Sounds of Then, Sounds of Now: Popular Music in Australia, ed. Shane Homan and Tony Mitchell (Hobart ,ACYS Publishing, 2008), 8090.

${ }^{43}$ See http://www.kavisha.com (Accessed 30 September 2008).

${ }^{44}$ See video "Kavisha Mazella: Australian Musician,” available at http://revver.com/video/594885/kavisha-mazzellaaustralian-musician-part-1 (Accessed 27 April 2009).

${ }^{45}$ Mary Waters, Ethnic Options: Choosing Identities in America (Berkeley: University of California Press, 1990), 19-20 and passim.
} 
Australian background, she has played with a number of eastern Mediterranean- and Middle Eastern-style groups since the 1990s. The music of such groups as The Habibis and Ta'esh Fa'esh has been based on music styles from Greece, the Eastern Mediterranean and Middle East. Harkin describes the inspiration that led her to this musical career as coming from the Antillean and Moroccan buskers she encountered in her first youthful period of international travel, in the excitingly exotic Arabic and African street markets of Paris's black arrondissements. Finding this music was part of a process that started when, in 1972, a twentyyear-old "Irish Catholic Australian . . had blundered into the strictly male domain of a Moroccan café," and eventually turned her into "an ex-Catholic Irish-Australian Middle Eastern/West African drummer." Travel was central to the self-definition of the musicians and audiences of Australia's growing multicultural music movement, and for many it extended far beyond the major European metropolises. This process turns music into a public expression of identity formation. In the third stage of cultural diversity politics, music need not be the representation of a particular social group or of the rights of specific ethnic groups to a share in the public culture.

Earlier models of multiculturalism acknowledged the legitimacy of stable intermediary ethnic organizations, conceptualized as "communities," to participate in connecting the citizen and the nation. The model of cultural diversity legitimizes the contingent flexible and hybrid identities that musicians project. World music genres became the dominant form of music supported by multicultural music organizations through the 1990s, and this was part of a shift in the mode of relationship of the individual and state. The music that now supports the new cosmopolitan citizen is characterized by a looser identification with social formations attached to ethnicity and history, but is equipped with the versatility that will enable the reassembled elements of earlier historic cultural forms to become an aesthetic asset to the nation. Thus cultural policy reproduces the way in which diversity is promoted as a valuable economic resource. ${ }^{47}$

This emphasis on identity is seen in the policy directions of the major multicultural music organizations currently operating in Australia. In the state of Victoria, for example, Multicultural Arts Victoria, supported by grants from state and federal levels of government, directs its most vigorous program of activity towards younger "emerging musicians" from non-English speaking ("culturally and linguistically diverse") backgrounds and towards musical creation which bears the traces of this background. These tend not to be semi-professional musicians catering to the tastes of a specific sociallydefined audience, but musical hopefuls who can be gently directed into making their music more clearly consonant with the expression of their "diverse identities." Kulcha, the Perth-based continuation of the North Perth Ethnic Music Centre (founded in the early 1980s by musician Linsey Pollack), exemplifies another perspective. Kulcha is best known as a fashionable acoustic music venue in Fremantle. Only some of the acts that perform there are marked as "ethnic" or culturally emblematic. Others include high quality acoustic performers or singer/song-writers with no specific claim to social difference. The criterion here is more an appeal to an afficionado musical taste than a representation of local ethnic communities. Kulcha's present day aesthetic has moved far from the "Café Folklorico" performances its predecessor staged in the 1980s and 1990s, which were dedicated to presenting local ethnic musicians to a wider audience. Instead it invites its cosmopolitan audiences into a favored venue that caters for their "omnivorous," adventurous,

\footnotetext{
${ }^{46}$ Anne Harkin, "Paris Africa," 3rd (Winter 1997): 23.

${ }^{47}$ Smith, Singing Australian, 161-64.
} 
and widely-embracing cultural tastes. ${ }^{48}$ Kultour, a national touring organization, is a consortium of statebased Multicultural Arts organizations dedicated to "bring[ing] multicultural arts into the mainstream." Supported by the Australia Council for the past five years, Kultour showcases the most professional of performances that highlight the expression of a culturally-based, but individually-realized expression, where multiculturalism is nuanced with high-status aesthetic innovation. ${ }^{49}$

The move away from a simple public musical indexing of multiculturalism as a federation of ethnic cultures towards a celebration of hybridity and diversity is reflected in the ways music has been used by performers to represent the nation. Since the 1970s, bipartisan policies of multiculturalism have become firmly established in public governmental policy at all levels. Despite the Howard government's attempts to limit the multiculturalism agenda in the second half of the 1990s, it remains firmly entrenched as an organizing feature of the nation. Policies linked with the specific engagements and projects of musicians have enabled them to use this cultural terrain as a place where imagining the nation state can take place. Through public multicultural music, Australians have been able to think about the relationship between larger social structures and their own points of personal identification. At this popular and personal level, multiculturalism has allowed flexible ambits within which individuals can move between international, transnational, and cosmopolitan centers of identity, and relate these to personal and local narratives. The musical forms that have been able to fit into these patterns of imagining national society often have ambiguous points of address. While tied to points of cultural authentication they are also thought of as freely available for adaptation and use; they can be deeply traditional and historically rooted as well as contemporary and newly-formed.

\begin{abstract}
Since the 1970s, the Australian State has adopted multiculturalism as a framework for policies of cultural expression and national representation. Over subsequent decades, the idea of multiculturalism developed from a simple depiction of a federation of ethnic cultures towards the celebration of hybridity and diversity, and this change has been reflected in the ways performers have used genres of music to characterize the nation. Shifting policies of the Australia Council, the most important arts funding body, have been influential. In its initial period the Council fostered folk-rock fusion bands and cultural revival genres. Fusion bands were seen as representing the multicultural nation, and cultural revival genres as authentic manifestations of stable cultural communities. As policies moved to emphasize diversity, hybridity, and the expression of identity, more fluid relationships with ethnicity became prominent. Thus policies have articulated with music to create ways in which the nation, and the relationship between the individual, community and the State, can be imagined.
\end{abstract}

\footnotetext{
${ }^{48}$ Richard Peterson and Roger M. Kern, “Changing Highbrow Tastes: From Snob to Omnivore,” American Sociological Review 61, no. 5 (October 1996): 900-7.

${ }^{49}$ See Kultour website, available at http://www.kultour.com.au/index.html (Accessed 27 April 2009); Jill Morgan (CEO of MAV), interview with the author, 11 August 2008.
} 